\title{
Late quaternary speleogenesis and landscape evolution in the northern Apennine evaporite areas
}

Andrea Columbu ${ }^{1 *}$, Veronica Chiarini ${ }^{2,3}$, Jo De Waele $^{2}$, Russell Drysdale ${ }^{1,3}$, Jon

Woodheâdd, John Hellstrom ${ }^{4}$ and Paolo Forti ${ }^{2}$

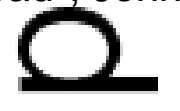

${ }^{1}$ School of Geography, University of Melbourne (Australia), University of Melbourne, 221

Bouverie stleet, 3010, Melbourne, Australia acolumbu@student.unimelb.edu.au; rnd@uniryejedu.au

${ }^{2}$ Department-gf Biological, Geological and Environmental Sciences, University of Bologna, Via Zamboni 67, 40127 Bologna, Italy vero.ch88@hotmail.it; jo.dewaele@unibo.it

${ }^{3}$ University of Savoie, Laboratoire EDYTEM, bd de la Mer Caspienne, Le Bourget du Lac cedex, F-73376, France

${ }^{4}$ School Of Earth Sciences, University of Melbourne, Corner Swanston \& Elgin streets, 3010, Mreloourne, Australia jdwood@unimelb.edu.au; j.hellstrom@unimelb.edu.au

*Corresponumg author: acolumbu@student.unimelb.edu.au

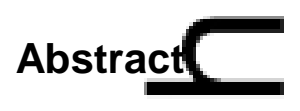

Gypsuntweus host the majority of the caves in the north-eastern flank of the Apennines, in the Emilia_Rdmagna region (Italy). More than six hundred of these caves have been surveyed cluding the longest known epigenic gypsum cave systems in the world (Spipola-Acquafredda, $\sim 11 \mathrm{~km}$ ). Although this area has been intensively studied from a

This is the author manuscript accepted for publication and has undergone full peer review but has not been through the copyediting, typesetting, pagination and proofreading process, which may lead to differences between this version and the Version of Record. Please cite this article as doi: 10.1002/esp.4099

This article is protected by copyright. All rights reserved. 
geological point of view, the age of the caves has never been investigated in detail. The rapid dissolution of gypsum and uplift history of the area have led to the long-held view that speleogenesis commenced only during the last 130,000 years.

Epigenic caves only form when the surface drainage system efficiently conveys water into the underground. In the study area, this was achieved after the dismantling of most of the imperviot covering the gypsum and the development of protovalleys and sinkholes The time necessary for these processes can by constrained by understanding when cares yere first formed.

The mining age of karst voids can be indirectly estimated by dating of the infilling sediment_- Th dating of carbonate speleothems growing in gypsum caves has been applied to 20 samples from 14 different caves from the Spipola-Acquafredda, Monte Tondo-Re Tiverio, Stella-Rio Basino, Monte Mauro, and Castelnuovo systems. The results show that: (i) caves were forming since at least $\sim 600 \mathrm{kyrs}$ ago; ii) the peak of speleogenesis was reached during relatively cold climate stages, when rivers formed terraces at tre surface and aggradation caused paragenesis in the stable cave levels; iii) -200,009 years were necessary for dismantling of most of the sediments covering the karstifiab gypsum and the development of a surface mature drainage network.

Besides providing a significant contribution to the understanding of evaporite karst evolution in the Apennines, this study refines our knowledge on the timescale of geomorphorgical processes in a region affected by rapid uplifting. 
Keywords: carbonate speleothems; evaporite karst; landscape evolution; cave formation; palaeoclimate

\section{Introduction}

Caves under two main hydrochemical conditions: epigenic and hypogenic (Klimcho $k$, 2007). Surface waters that derive their aggressiveness from the land surface and the tmophere carve epigenic caves, while fluids attaining their acidity from deep sources $\mathrm{H}_{2} \mathrm{~S}$ or $\mathrm{CO}_{2}$, or mixing of two different solutions such as in coastal settings) often happening deep below the Earth surface, can act over very long time spans (Polyak, 1998). Epryetric speleogenesis, on the other hand, occurs closer to the land surface, and erosionaloses tend to intercept karst voids in a few millions of years.

Karst dynamics are intimately associated with environmental variations at the surface (Ford anurvimiams, 2007), and the chronological refinement of dissolution processes and karst history may help us to better understand base-level (i.e. local water table) variation, which is elatgd to geological events such as uplift and other tectonic movements, as well as valley incion. In this regard, the study of epigenic caves carved in gypsum provides some adyantages compared to those hosted in limestone/dolostone. Gypsum is highly soluble, antit speleogenesis occurs up to hundred times faster than in carbonates (Klimchouk, 2000). The explorable caves at present, if not confined in deeper levels of the geologicar Sequence (i.e. hypogenic Ukrainian systems, Klimchouk, 2012), must be 
relatively young because the rapid underground erosion combined with surface weathering lead inevitably to the fast dismantling of the bedrock, demolishing the underlying caves. On the other hand, high gypsum solubility provides an almost contemporaneous response of speleogenesis to surface climatic and environmental changes, even at intraMilankovitch timescales (Columbu et al., 2015). It follows that dating epigenic gypsum caves of double opportunity of constraining the timing of cave formation and allowing better understanding of the link between external and underground geological processe Gonsequently, because of the link between epigenic caves and surface realms, yajestanding the age of the first proto-caves provides important insights on the timing of gnomorphological evolution at the surface. Specifically, it constrains the time necessary for: 1) the exhumation of the karst terrain (i.e. when karstifiable bedrock is no longer conmmed and starts to undergo surface weathering and erosion), and ii) the developmen surface drainage capable to efficiently convey water into the subterranteys system, thus forming epigenic caves (i.e. formation of protovalleys, sinkholes, and dolines).

One of the most intriguing - yet complicated - conundrums when studying the genesis and evolution or gyve systems is an understanding of the exact timing of void formation, i.e., the problemaf assigning a numeric age to "what is not there" (Sasowsky, 1998); a range of strategies bave been proposed in order to overcome this problem. The ages obtained by the traing of alunite in Carlsbad and Lechuguilla caves are considered contemporapgous with the formation of the cave passages (Polyak et al., 1998), because this minerarforms when the acidic cave-forming waters encounter clays. In the same area, 
dolomite has also been reported as a speleogenetic byproduct (Polyak et al., 2016) Similarly, replacement gypsum in sulphuric-acid caves can provide reliable ages of cave formation, as long as gypsum did not undergo alteration - and did not loose uranium - over time (Plan et al., 2012; Piccini et al., 2015). These can be considered the nearest direct approaches to dating a void. However, the survival of alunite and/or gypsum is restricted to those parosine cave that have never experienced flooding, dripping or seepage since their fornation. In addition, formation of speleogenetic dolomite is possible in restricted circumstafces. Also, these minerals are only found in sulphuric-acid caves, strongly limiting treayjlisation of this direct-dating approach. As a result, karst voids are mostly indirectly alated (Audra et al., 2006) using a range of infilling materials that logically are formed subsequent to the carving of the cave. These materials include sediments, archaeological remains, fossils and speleothems.

The spelenesis of epigenic limestone and dolostone karst systems is often driven by changes of the local base-level at the surface (Williams, 1982; Ford and Williams 2007). This mearis that bedrock exhumation, allowing the start of speleogenesis, may have happene many millions of years ago. Additionally, with the exception of tropical environments(Farrant et al., 1995; Audra et al., 2011), cave development in carbonate rocks is warocess (White, 1988). It follows that the formation of those karst networks currently showing complex multi-kilometric extensions may have begun several millions of years beforgpresent (De Waele et al., 2012a; Tassy et al., 2013; Calvet et al., 2015; Häuselmann al al., 2015). In such cases the datable materials traceable to the first stages of cave evowion may have been irretrievably lost, and even the primordial asset of the 
karst passages is likely overwritten by more recent speleogenetic phenomena. For example, dated speleothems from the middle levels ( $\sim 900 \mathrm{~m}$ a.s.I.) of the Corchia system (central Italy) approach one million years in age (Woodhead et al., 2006; Bajo et al., 2012), while the exhumation of the area occurred not earlier than 5.0-4.5 Ma ago (Balestrieri et al., 2003). The formation of the earliest upper levels ( 1400 m a.s.l.) is assigned to the Late Plioniccini, 2011), and further U/Pb dating of speleothems from the highest cave levels would be needed to refine this chronological constraint.

We studif soral still-active karst systems carved in the gypsum sequence outcropping in the Notyeng Apennine foothills, Emilia Romagna region, Italy (De Waele et al., 2011). Earlier stuling have also reported Late Messinian karst systems in this area, now entirely filled with sediments. These 5 million year old cave segments have formed before the gypsum Stquence was covered with the thick less permeable Argille Azzurre Fm. and tilted in Satual monocline position (De Waele and Pasini, 2013). Epigenic caves in gypsum now hot have formed since the Late Messinian submersion, and the most recent karst cycte started only after the Apennines emerged from the sea and most of the covering sediments were removed from the gypsum sequence. In this portion of the Apennine pleymont, karst networks are mostly composed of superimposed, more or less horizontaltwanels that reflect the position of past local base levels (Columbu et al., 2015). We integrated the U-Th dating of twenty carbonate speleothems, which provide minimum ages of theyssages in which they grew, with in-cave and external morphological features that are indicators of the palaeo base levels. These data have then been combined with regional geugical relationships to document the Quaternary evolution of the underground 
and surface drainage of the area of study. The main aims and motivations of the paper therefore are:

1) To establish the timing of the inception of speleogenesis. For the aforementioned reasons the ages of these caves have been largely underestimated in the past. Previous research'has linked the speleogenesis to the last 130,000 years (Demaria, 2002; Forti, 2003; Pami, archaeolggical (Miari, 2007; Negrini, 2007) and paleontological (Pasini, 1969) findings have corrobotated this idea.

2) To undegand the periods during which the excavation of the different cave levels constitutingthe systems was most effective.

3) To evaluate the time necessary for the dismantling of impervious rocks originally covering the tharstifiable gypsum unit and for the excavation of the first valleys, dolines and sinkholes allowed the penetration of water into the epigenic karst network.

Considerimgthe above-said link between the subterranean and surface environments, the outcomes mray reinforce our knowledge of the connection between the rapid uplift that is characterstic of the study area (Cyr and Granger, 2008; Picotti and Pazzaglia, 2008) and the lands apg evolution of the middle to upper Pleistocene.

\section{Study area}

We explerenfive karst systems located in the northern Apennine piedmont (EmiliaRomagna region), carved in the Vena del Gesso (= Gypsum vein) formation (Vai and Martini, 2001-i Lugli et al., 2010): Spipola-Acquafredda, Monte Tondo-Re Tiberio, Stella- 
Rio Basino, Monte Mauro and Castelnuovo (Figure 1). The first lies at the south-eastern periphery of Bologna (Figure $2 \mathrm{~A}$ ), while the remaining caves are situated $\sim 40 \mathrm{~km}$ southeast of the city (south of the city of Imola), where the gypsum vein outcrops with its classical cuesta-like morphology (Figure 2B). The gypsum vein is mostly composed by macrocrystallyne selenitic gypsum. In macrocrystalline gypsum, pervasive primary porosity is scarce vadose actures and joints originated by tectonic and/or diagenesis. Superficial karst landform are also well developed in the study area (i.e. dolines and blind valleys, Figure 2), having pyimary role in the current and past development of the underground drainage network. outcrops, was deposited during the Messinian Salinity crisis (Krijgsman et al., 1999; Roveri et al., 2014. In the Northern Apennines, it is exposed along a NW-SE elongated belt connectirla peaks of the mountain chain in the south with the Po plain foredeep in the north (FIgice 1). The structure of the caves comprising the explored karst systems is intimatery rerated to the geological and environmental factors that have characterised the area singe the uplift of the Apennines. First, the majority of caves follow NW-SE tectonic features Deyaele and Piccini, 2008); less frequently WNW-ESE and W-E lineaments, or the SW-NICanti-Apennine directions, are exploited. Second, all caverns are epigenic (Klimchouk, 2000), developed in an unconfined aquifer in the first few hundred metres of the exposedredrock. Considering that the karst conduits convey the infiltrating waters to the local bace level, the altitude and elongation of the caves is related to base-level oscillations bver time, associated with Quaternary climate changes and uplift (Columbu et 
al., 2015). Several superimposed levels constitute the Spipola-Acquafredda and Monte Tondo systems, of which only the lowermost is currently active. Two levels form the Castelnuovo system and the Stella-Basino system, possibly reflecting the younger age of these two networks (Chiarini et al., 2015). At Monte Mauro, on the other hand, the Grotta dei Banditi (Bandit cave) is the only branch left of a much bigger cave system, now complete fermains of carbonate flowstones that can still be found at the surface close to Grotta dei Banditi are all that is left of the other branches of this system. In fact, any revie on the gypsum caves in the Emilia-Romagna territories should also consider those caye visible today, destroyed by the continuous surface and subterraneanerosion of the soft gypsum beds.

\section{Materitarsand methods}

In order 6 mote cave conservation (Fairchild and Baker 2012; Scroxton et al., 2016), no in siturarbonate speleothems were removed; samples were principally found as broken specmens inside the caves. In a few cases, speleothems were subjected to core drilling (Spötl and Mattey 2012; Figure 2C) or found at the surface, in the vicinity of the cave entrance. Six flowstones were collected at the Monte Tondo-Re Tiberio system (RTf, A50, 3A, PP and GO) (Figure 2E). The first was found in the quarry at $\sim 340$ metres a.s.l., while the remaining samples were collected in cave galleries respectively at 270 , 220, 180, $10 \mathrm{y}$ and 130 metres a.s.I. Two flowstones and one stalagmite were sampled in both the Spipola-Acquafredda and Castelnuovo karst systems. In the first, the SpD flowstone was found at the Croara quarry (250 metres a.s.I.) close to the Spipola doline 
(Figure 2E) (Forti and Sauro, 1996), the Sp1 flowstone cored in a cave level at $120 \mathrm{~m}$ a.s.l. (Figure 2D) and SpS found in a cave level at $125 \mathrm{~m}$ a.s.l. In Castelnuovo, the Mor2 stalagmite was found in the Mornig cave at $190 \mathrm{~m}$ a.s.l, the P2 flowstone was recovered at the surface at $180 \mathrm{~m}$ a.s.I and the P3 flowstone was cored in a cave level at $185 \mathrm{~m}$ a.s.l. The exploration of the Monte Mauro cave system allowed us to recover a large stalagmite (BA_Big) Banditi Cave at $450 \mathrm{~m}$ a.s.l., and two flowstones (Ba1 and Ba2) near the -

cave but the surface (unroofed remains of a larger cave system). Two other flowstones (MM4 an MN2) were taken at the surface close to the highest elevation of Monte Mauro, around $480 / 490 \mathrm{~m}$ a.s.l. Three flowstones also come from the Stella-Rio Basino system: RBT wasfound at the surface at $160 \mathrm{~m}$ a.s.l, RB1 and RB3 collected underground at 170 $\mathrm{m}$ a.s.l. The predominance of flowstones over stalagmites is not a sampling bias: stalagmites are generally extremely rare in the Northern Apennine gypsum karst. Refer to Figure 3 artbe size and macroscopic fabric of the samples.

The speleothems were sliced in two with a diamond saw. The analyses were performed on the fresn surnace of one half after polishing; the other half was archived. The sub-samples (calcite pisms) used for the U-Th dating weighed between 10 and $120 \mathrm{mg}$, and were drilled algnge growth layers using a dental hand-drill. The dating aimed to recover the base and page of all the speleothems. When the stratigraphic bottom/top was considered unsuitable for dating (i.e. due to the visible presence of detrital material in the carbonate-ragjers, evidence of carbonate dissolution, etc.), samples were taken of the closest cleap and unaltered calcite. Intermediate ages were also determined in order to improve the ahronological control of the longest samples. 
In total, $70 \mathrm{U}$-Th ages were produced. The sub-samples, the drilling locations of which are reported in Figure 3, were first dissolved in $\mathrm{HNO}_{3}$ following the procedure of Hellstrom (2003). A spike of known ${ }^{236} \mathrm{U} /{ }^{233} \mathrm{U} /{ }^{229} \mathrm{Th}$ ratio was added to the solution and the U-Th fraction was separated from the carbonate matrix using Eichrom TRU-Spec resin in columns. The $U$ and Th fractions were collected together and evaporated overnight at $80^{\circ} \mathrm{C}$ befoing taken up in $5 \% \mathrm{HNO} / 0.5 \% \mathrm{HF}$ ready for isotopic analysis. The majority f measurements were performed on a Nu Plasma multi collector - inductively coupled lasna - mass spectrometer (MC-ICP-MS) at the School of Earth Sciences, The University Melbourne, following the methodology established in Hellstrom (2003) and refined in aryolale et al. (2012). Three samples were instead analysed at the Laboratoire des Sciences du Climat et de l'Environnement (LSCE) at Gif-sur-Yvette (France) according with Pons-Branchu et al. (2014) (Table 1). Th-corrected U-Th ages were calculate 1 sing equation 1 of Hellstrom (2006) with the ${ }^{230} \mathrm{Th}^{234} \mathrm{U}$ decay constants of Cheng etal (2013) and an initial $\left({ }^{230} \mathrm{Th}^{1232} \mathrm{Th}\right)_{\mathrm{i}}$ of $1.5 \pm 1.5$. Samples were analysed in batches OI Z4 with eight accompanying HU-1 Harwell Uraninite measurements, and reported activity ratio uncertainties are expanded by the observed standard deviations of the stancaras Age uncertainties are approximated as symmetric, except for the oldest samples whare separate upper and lower uncertainty bounds were calculated.

\section{Resulto}

In general, the speleothem ages produced realistic radiometric ages, with samples possessing high content of ${ }^{238} \mathrm{U}$ and, for the most part, a high ${ }^{230 / 232} \mathrm{Th}$ activity ratio 
$\left({ }^{230} \mathrm{Th}^{1232} \mathrm{Th}\right.$; Table 1). ${ }^{238} \mathrm{U}$ is never below $290 \mathrm{ng} / \mathrm{g}$, with maximum concentrations exceeding $3000 \mathrm{ng} / \mathrm{g}$, and with an average value of $1206 \mathrm{ng} / \mathrm{g}$. ( ${ }^{230} \mathrm{Th}^{1232} \mathrm{Th}$ ) averages $\sim 8000$, but it correlates with the age of the speleothems. The Holocene samples report the lowest values $(<10)$, followed by speleothems deposited during the early last glacial (100200). In older samples (i.e. last interglacial or older) this ratio is two to three orders of magnituderter. Initial ${ }^{232} \mathrm{Th}$ content has an important role in determining the $2 \sigma$ uncertain $y$ associated with the final age. Young samples possess relatively small amounts of authig (nic ${ }^{30} \mathrm{Th}$, thus $\left({ }^{230} \mathrm{Th}^{/ 232} \mathrm{Th}\right)$ and corrected age uncertainty are highly sensitive to thorium deriggd from non-authigenic sources. For this reason, the uncertainties relative to the Holoconnages are, in percentage terms, greater than the other samples.

The final corrected ages and the associated errors are reported in Table 1. A comparison of speleotrmm age with the main climatic stages over the last $\sim 800 \mathrm{ka}$ is provided in Figure 4. The canbilation follows the subdivision of the marine isotopic stages (MIS; Emiliani, 1955) on global 'LR04' $\delta^{18} \mathrm{O}$ benthic stack proposed by Lisiecki and Raymo (2005). Four spereourems grew during the last two millennia of the Holocene (MIS1) (RTy, Sp1, SpS, andRB3) while seven speleothems span from the middle (Mor2, RB1, RBT, and P3) to the ea Holocene (GO and P2). Flowstones 3A, PP, and A50 were deposited during shorts interals of the period ranging from $\sim 110 \mathrm{ka}$ to $\sim 70 \mathrm{ka}$, the transitional phase from the last interglacial (MIS 5e) to the last glacial, characterised by the Greenland Interstadial (GI) and Srajal (GS) oscillation (NGRIP project members, 2004). Speleothem 3A formed from 108.86 0.98 to $106.29 \pm 7.23 \mathrm{ka}$, PP from $87.80 \pm 0.70$ to $75.21 \pm 1.44 \mathrm{ka}$ and A50 from $77.89 \pm 6.06$ to $74.69 \pm 0.68 \mathrm{ka}$, correlated respectively with $\mathrm{Gl} 24$ and $21-20$ 
(Columbu et al., 2015). Two speleothems formed during the last interglacial: RTf and Ba_Big. They were mainly deposited during the climatic climax ( 130-120 ka, MIS 5e), although the upper portion of the Ba_Big stalagmite grew across the LIG-glacial transition (top age $112.36 \pm 1.09 \mathrm{ka}$ ). Flowstone SpD started to grow during the last phase of the glaciation corresponding to the MIS 8, but was mostly formed during the MIS 7e, from $253.90 \pm 239.34 \pm 4.30 \mathrm{ka}$. Two flowstones from the Monte Mauro system, MM4 and MM2 reported bottom ages much older than the top ages. MM4 bottom is at 468.00 ${ }^{+130} \%_{-42} \mathrm{ka}$ (MI) 13 considering the average age, MIS 12 to 15 considering the error) and the top a $44 \pm 14.27 \mathrm{ka}$ (MIS 9), MM2 bottom is at $316.17 \pm 12.65 \mathrm{ka}$ (MIS 9) and the top at 230 a $4.46 \mathrm{ka}$ (MIS 7e). Although intermediate ages between the bottom and the top of these last two speleothems were not done, petrographic evidence shows that the deposition of the carbonate was not continuous but characterised by growth interruptions. Ba1 and ${ }_{2}$ belonging to the same karst system, report only one age each respectively at $689 \pm 369.10 \mathrm{ka}$ (bottom age) and $378.26 \pm{ }^{+29} /-20 \mathrm{ka}$ (top age). Although the large uncertannty, we are 95\% confident that Ba1 is older than $580 \mathrm{ka}$, and might coincide with MIS 15. \&a2 instead might fit with the latest part of MIS 11.

\section{Discuscion}

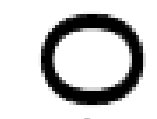

Messinian gypsum caves in South Spain were formed in a semi-confined aquifer since the lower Pletsogene (Calaforra and Pulido Bosch, 2003). Marly strata intercalated with gypsum beda drove the speleogenesis creating the first proto-conduits under phreatic conditions, which later developed into a multi-level cave system following river 
entrenchment and vadose erosion. Several field evidences testify this process, such as "V" shaped passages, meandering braided pendants, ceiling channels and gypsum layer breakdown in the cave roofs as relict of the ancient speleogenetic evolution (Calaforra and Pulido Bosch, 2003). The situation is quite different in our area of study. All caves levels are -horizontal, while the gypsum sequence is tilted (from $20^{\circ}$ to $45^{\circ}$, De Waele and Pasini, 2C.This means that marly strata did not controlled speleogenesis. We recently demonst the formation of caves composing the Monte Tondo karst system was related t clithate-driven base level oscillations over the last $\sim 130,000$, occurred in an unconfinged gquifer (Columbu et al., 2015). The formation of epigenic caves in macrocryctalline gypsum is only possible once the soluble rocks are emerged and in contact with undersaturated fresh water. The Vena del Gesso gypsum formation was originally covered by marine silts and clays of the Argille Azzurre (sky-blue clays) formation(Dorosi et al., 1998), deposited from $\sim 5.3 \mathrm{Ma}$ to $\sim 1.8 \mathrm{Ma}$, followed by the Sabbie Gidle (yellow sands) formation (Antoniazzi et al., 1993; Cyr and Granger, 2008) (Figure 5 ). The latter is mostly comprised of littoral marine sandstone (Marabini et al., 1995) deposited during Early Pleistocene phases of sea-level high stands. The top age of the Sablegialle is attested at 780-820 ka, provided by electron spin resonance and palaeomagnatic calculations (Antoniazzi et al., 1993; Falgueres, 2003; Muttoni et al., 2011). This age ( $800 \mathrm{ka}$ ) marks the beginning of the so-called "continental Quaternary" (Benini 1999; Amorosi et al., 2015), which in the local sequence stratigraphy comprises allsediments deposited after the definitive regression of the Adriatic Sea. From a speleogentic perspective, it defines the potential maximum age for the beginning of the 
development of the oldest epigenic caves. The emergence of the Apennine piedmont resulted from the rapid uplifting of the area, calculated at $0.2-0.3 \mathrm{~mm} / \mathrm{year}$ around the middle Pleistocene (Cyr and Granger, 2008; Picotti and Pazzaglia, 2008). The retreat of the shoreline was possibly fuelled by the Middle Pleistocene Transition (Pisias and Moore, 1981; Muttoni et al., 2003; Maslin and Ridgwell, 2005), after which the severity of glaciation ineased.

It is unlikely that speleogenesis started as soon as the sea retreated. All caves show epigenic ņorghology, characterised by typical gypsum through-flow conduits (Klimchouk, 2000). A cy gyorizontal cave tunnel is excavated parallel to the piezometric level at the same altitudas the base level. This implies that: i) the majority of the sediments originally covering the gypsum karst terrain (i.e. Argille Azzurre clays and Imola sands) were removed the commencement of the epigenic speleogenesis; and ii) the superficial drainage sustem already developed a certain status of maturity, sustaining the valley incision and creating the altitudinal gradient necessary for the flow of the groundwater (Figure 5). Tme oldest river terrace (Qt0) preserved along the Bidente and Reno valleys, located respectively to the north and to the south of the study area, has no numerical ages (Figure 4 - Yrough stratigraphical correlation with the equivalent Po Plain foredeep sediment_is_is tentatively assigned to one of the MIS 22, MIS 20, or MIS 18 glaciation peaks (Gyr and Granger, 2008; Picotti and Pazzaglia, 2008; Wegmann and Pazzaglia, 2009), respogtively at $\sim 870, \sim 800$ and $\sim 740 \mathrm{ka}$. Thus, proto valleys already developed at least by $\sim 740 \mathrm{ka}$, which is $60-80$ kyrs after the definitive emergence of the area. However, the hydrological network was possibly fully efficient between 400 and 500 ka, when the 
first alluvial fans were deposited in the Padana foredeep (Gunderson et al., 2014; Amorosi et al., 2015).

When comparing the minimum ages of the samples with global climatic variations over the last $\sim 800$ ka (Lisiecki and Raymo, 2005), it is worth noting that the presence of carbonate speleothems coincides with stages of climate optima (Figure 4), in line with our previous work bas speleothems from Monte Tondo (Columbu et al., 2015). Speleothems were maily formed during the peak interglacial periods (Holocene, MIS5e, MIS7e, MIS9, MIS11), (ith yvo of them potentially linkable to MIS13 (MM4 flowstone) and MIS 15 (Ba1). Although ing glacials do vary in terms of duration, average temperatures and rainfall dynamics (Tzedakis et al., 2009), these periods are recognised as the emblems of considerably warm and wet climate (Sirocko et al., 2006). The influence of climate on the deposition the speleothems is also evident in an intra glacial/interglacial timescale. GO, PP and 5 lowstones formed during the Greenland interstadials (GIS) 24, 21, and 20 respectively (Figure 4). GIS are rapid returns to an interglacial-like climate (although generany ress warm) during an otherwise glacial period (Dansgaard et al., 1993). Enhance rainfall and humidity is the most suitable condition for the development of pervasive vegetation in the piedmont hillslopes. From a geochemical point of view, this means that the overabundance of biogenic $\mathrm{CO}_{2}$ released by the pedogenic layers at the surface has a key impact in the production of carbonate speleothems once the waters percolateingthe gypsum caves (Borsato et al., 2015).

From a geomorphological perspective, a thicker vegetation cover protects the hillslopes from surfac arosion during these warmer and wetter periods. The availability of sediments 
on the slopes is reduced when compared to relatively colder climates. In southern Italy, pollen data indicate that glacial climates favoured the expansion of steppe-like and bush vegetation (Allen and Huntley, 2009). In this circumstance, the bedrock is largely exposed to weathering processes; the resulting regolith is gravitationally conveyed toward the bottom of the slopes, usually constituted by the active base level valley (Simoni et al., 2013). Censung the latitudinal difference between the southern side of the peninsula and the orthern Apennines, it is likely that in the studied area this vegetation persisted beyond tre pyak of the glaciations, prolonging conditions conducive to maximum regolith productio(?)

The fluvialmaraaces preserved in the main rivers draining the northern Apennines (Bidente and Reno rivers) were all formed during these periods of abundant regolith production (Wegmarmand Pazzaglia, 2009) (Figure 4). Besides the aforementioned Qt0 generation, terrace Q1 Drrelates with MIS16, Qt2 with MIS12 or MIS10, Qt3 with MIS6, Qt4 with MIS4 and with MIS2 (younger fluvial terraces are also known from the Holocene, but are not reported in Figure 4). The presence of a terrace deposit testifies that the river maintaing $\mathrm{a} \sim$ stable palaeo-altitudinal position necessary for the aggradation of the slope sediment $\mathrm{In}$ the river trunk. These periods of stability were longer than 1,000 years (Wegmannand Pazzaglia, 2009); the alluviated valleys were incised by a lowering of the base level under a different climate regime. The epigenic karst systems are strictly connecterig the local base-level variation. When the base level lowers, karstification proceeds vertically, in the same way rivers entrench the valley bottoms. The Apennine gypsum Karas shows evidence of this process through deep and narrow shafts; in the 
Monte Tondo cave network, the Pozzo Pellegrini shaft is more than 30 metres deep (De Waele et al., 2013). In contrast, when the river establishes a new altitudinal position, underground waters run according to the new piezometric level. The accumulation of slope sediments forms alluvial valleys that, at the millennial scale, act as new stable base levels for the karst systems. The main sub-horizontal cave tunnels are thus excavated during these staterve intervals.

Five superimposed cave levels are particularly well preserved in the Monte Tondo-Re Tiberio karst system. The connection between the fluvial dynamics and speleogenetic processe the the prified by the paragenetic canyons in several of the cave ceilings (Docini 1966, 1967, 1973). When the supply of slope material exceeds the maximum bed load sustainable by the river flow, aggradation occurs in the valley bottom pushing trocal base level slowly upward. In response, underground conduits also accumuldesdiments and the running waters erode the cave ceilings through so-called antigravitative erosion process (Pasini, 2009). Taking into account the cyclical stability of the base Tever witnessed by the river terraces and the stacked-like nature of the gypsum karst systems carved in the north Apennine piedmont, we attribute the excavation of the sub-horiz nta cave tunnels to periods of relative colder climate (Figure 4 and 6). River terraces present at the same altitude as the main cave levels of the studied area (Columby et al., 2015). Although they have not always been dated, their formation should correspond the same genetic dynamics controlling the hydrogeology of the area (Wegmann and Pazzaglia, 2009), being deposited during cold stages. However, the ages of the spelethems provide an indication of the minimal age of the cave tunnels (and thus 
the related terraces). When terraces and caves are in the formation stage, the result is underground passages completely filled by water, and vadose speleothem deposition is not possible. Once these new caves are drained, following renewed entrenchment of the river, speleothem formation can start (Columbu et al., 2015). Because cold-periods favouring the excavation of the cave voids are followed by warm periods favouring speleothesition, it is feasible to assign the speleogenesis of a certain cave level to the first old-period preceding the oldest speleothem age sampled in that cave (Figure 6). It could be argued that speleothems might have formed even thousands of years after the drainage of the cave, confounding our understanding of the age of speleogenesis. This cannot, ofeatrse, be excluded in this study. However, there is a good agreement between the antiquity of the speleothems and the altitude of the caves in which they were found (Figure 7, 7 the Monte Tondo-Re Tiberio system, RT flowstone - recovered at $\sim 340$ metres a. - was deposited $\sim 130 \mathrm{kyr}$ years ago (Columbu et al., 2015). The speleothems sampled close to the actual base level in the cave ( 95 metres a.s.I.) were Holocene In age. Those speleothems sampled in between these two cave levels report intermediate ages. In general, all the oldest speleothems come from the highest-altitude cave levers. She speleothems older than $300 \mathrm{ka}$, coming from the Monte Mauro system, have all an recovered at altitudes higher than 400 metres a.s.l., the most elevated portions of the Apennine foothills (Figure 7). Thus the chronology of the speleothem productionfoys an altitudinal gradient, which in turn mirrors the progressive base leveldriven downward migration of the speleogenetic processes. 
The oldest speleothems in our collection provides a basal age of >580 ka (Ba1) and $468.00^{+130} /-42$ ka (MM4 flowstone). This suggests that caves already existed in the area at least since MIS15 (i.e. 600 kyrs ago, testified by Ba1 age and the oldest possible MM4 age). Assigning the timing of speleogenesis to the coldest period just before MIS15 (MIS16), the excavation of the first caves likely occurred at least 630 kyrs ago, 200 kyrs after the emergence of the area. This timespan ( $200 \mathrm{kyrs})$ appears sufficiently long for $\$$ veral reasons. First, there is adequate time for the erosion of the majority of the marine s dim covering the area and the gypsum beds, fuelled by the rapid uplifting of the area $C_{y}$ ently, in many watersheds, these sediments are visible as uplifted fluvial terraces Pintti and Pazzaglia, 2008; Wegmann and Pazzaglia, 2009). Second, it is a reasonable timeframe for the formation of a drainage network, which will later develop into deep rivervalteys. The age of the caves at $\sim 630 \mathrm{ka}$ is considerably close to the time of the formation for first alluvial fan in the Padana foredeep (Gunderson et al., 2014; Amorosi et al., 2015) symptomatic of the general maturity of the fluvial system. Finally, there is sufficient tume for triggering the geomorphological phenomenon known as "relief inversion" (Pain and Oilier, 1995) (Figure 5). Nowadays, gypsum beds stand out as prominent cuesta-lik rigges because of the differential erosion of the adjacent formations (De Waele et al., 2012h)_(Figure 2B). Whereas in the non-soluble terrains surface erosion leads to a progressive lowering of the ground level, enhanced by the rapid uplifting of the area, in gypsum oulk of the erosion is transferred underground. When gypsum was first exposed, the rivers descending from the upper part of the foothills penetrated the karst rocks, inttraing blind valleys at the contact between soluble and non-soluble terrains 
(Figure 5). The Rio Stella blind valley is today an excellent example of this style of surface versus subterraneous drainage (De Waele, 2010). Sinkholes also facilitated the penetration of the water into the karst systems. The large Spipola doline close to Bologna, with a diameter of more than 500 metres, is one of the most striking examples (Forti and Sauro, 1996) (Figure 2A). Around six hundreds years ago, the first proto-caves transferred surface into the downstream main river throughout karst springs, at least in the Monte Mauro and Banditi caves where MM4 and Ba1 flowstone were found. Large portions the first caves have been now disaggregated. At the same time the flowstone collected inge Spipola doline (close to Bologna), dated at $\sim 250 \mathrm{ka}$, testifies to the formation-fhe caves in this area from at least 260,000 years ago; these old caves, probably forming the upper levels of the current levels constituting the SpipolaAcquafreurasystem, have also been eroded.

\section{ত}

\section{Concrusigns}

This stuuy reports the U-Th radiometric dating of twenty carbonate speleothems sampled in the Messinian gypsum karst areas of the northern Apennines. In agreement with previous vom based on speleothems recovered from the Monte Tondo-Re Tiberio karst system, thege of the samples fits with periods of warm and wet climate. Specifically, the speleothems forrelate with the current (Holocene) and previous interglacials (MIS 5e, 7e, 9, 11, 13antiverobably 15) and the Greenland interstadials 24, 21 and 20. The basal age of the spelenthems provides an indication on the minimum age of the cave passages in which they are found. The age of the speleothems found at the surface testify to the 
presence of past cave levels that have been partially or completely destroyed by surface denudation. The main sub-horizontal cave tunnels constituting the explored karst system formed when the palaeo-base level stabilized at a new altitudinal position during cold-dry climate stages. In these periods, vegetation-free hillslopes saw high amounts of regolith transported downslope to the trunk river valley, after which subsequent incision formed river terres the same altitude of the cave levels. The available ages of the river terrace formations in the area corroborate the correlation between speleogenesis and periods reftively cold and dry climate. Considering the age of the speleothems, the formation co associated cave passages were assigned to the cold-dry climate stage immediatemefore the warm-wet phase attributed to speleothem growth.

This study has important implications for understanding the timing of underground and surface dramrage systems development in rapidly uplifting areas. Firstly, it reviewed the duration 1 speleogenesis in Northern Italian gypsum terrains, which has been underestmated until now. In the Monte Mauro area, caves were already forming at least $-630,000$ years ago, 200,000 years after the emergence of the Apennine piedmont. It follows that this time period was necessary for the erosion of most of the sediments covering neypsum sequence, the incision of the proto valleys and the creation of the karst sinkbolos, the latter introducing the majority of surface waters into the subterranean voids. Furthermore, the carving of epigenic caves was enhanced once the phenomenon of relief inversiog exposed the gypsum sequence as a karstificable ridge among non-soluble terrains. In the Spipola area close to Bologna, caves were present at least 260,000 years ago. These ald cave conduits have mostly been destroyed by surface denudation of the 
gypsum bedrock, while the carbonate speleothems that decorated their walls/floors have been better preserved and can still be found scattered across the surface.

\section{Acknowledgments}

We than project. We are grateful to Garibaldi (Baldo) Sansavini, Massimo Ercolani, Piero Lucci, Luca Gr langj, Roberto Evilio, Katia Poletti, Alessandro Pirazzini, Alan Nardi, Luca Tarozzi, Minele Castrovilli, Roberto Cortelli, Francesco Grazioli, Fabio Giannuzzi and Ilenia Mariam'Angeli for their tireless help during the fieldwork. Comments by David Richards and an anonymous reviewers, as well as by Prof. Lane and an associate editor have helpeuminimproving our manuscript.

\section{Referencos}

\section{(ర)}

Allen JRIV, Funtley B. 2009. Last Interglacial palaeovegetation, palaeoenvironments and chyonology: a new record from Lago Grande di Monticchio, southern Italy. Qyateyary Science Reviews, 28(15): 1521-1538.

Amorosi faporale L, Cibin U, Colalongo M, Pasini G, Ricci Lucchi F, Severi P, Vaiani S. 19.98. The Pleistocene littoral deposits (Imola Sands) of the northern Apennines foGumy. Giornale di Geologia, 60: 83-118. 
Amorosi A, Maselli V, Trincardi F. 2015. Onshore to offshore anatomy of a late Quaternary source-to-sink system (Po Plain-Adriatic Sea, Italy). Earth-Science Reviews, 153: 212-237.

Antoniazzi A, Ferrari M, Peretto C. 1993. Il giacimento di Ca'Belvedere di Monte Poggiolo detPleistocene inferiore con industria litica (Forli). Bullettino di Paletnologia Italiana, 8

Audra P, Bini A, Gabrovšek F, Häuselmann P, Hobléa F, Jeannin P-Y, Kunaver J, M ńba)on M, Šušteršić F, Tognini P. 2006. Cave genesis in the Alps between the Mirc and today: a review. Zeitschrift für Geomorphologie, 50(2): 153-176.

Audra P, Mountains (New Britain, Papua New-Guinea). Evolution model of a juvenile system (MurunCave) inferred from U/Th and paleomagnetic dating. Speleogenesis and Evatuion of Karst Aquifers, 10: 25-30.

Bajo P, Brysdale R, Woodhead J, Hellstrom J, Zanchetta G. 2012. High-resolution U-Pb araung of an Early Pleistocene stalagmite from Corchia Cave (central Italy).

Quaternary Geochronology, 14: 5-17.

Balestrie IV, Bernet M, Brandon MT, Picotti V, Reiners P, Zattin M. 2003. Pliocene and Pleictesene exhumation and uplift of two key areas of the Northern Apennines. Qyaternary International, 101: 67-73.

Benini A, tvratyelli L, Amorosi A, Martini A, Severi P, Cazzoli MA, Vaiani SC. 1999. Note illustrative della carta geologica d'Italia alla scala 1:50.000. Servizio Geologico d'Itainom Roma. 
Borsato A, Frisia S, Miorandi E. 2015. Carbon dioxide concentration in temperate climate caves and parent soils over an altitudinal gradient and its influence on speleothem growth and fabrics. Earth Surface Processes and Landforms, 40(9): 1158-1170.

Calaforra, JM., Pulido-Bosch, A. 2003, Evolution of the gypsum karst of Sorbas (SE spain). Geomorphology, 50: 173-180.

Calvet M,

Tetam. 2015. Cave levels as proxies for measuring post-orogenic uplift: Evidence

frons cosmogenic dating of alluvium-filled caves in the French Pyrenees.

Gqorigrphology, 246: 617-633.

Cheng Hanrence Edwards R, Shen C-C, Polyak VJ, Asmerom Y, Woodhead J,

Hellstrom J, Wang Y, Kong X, Spötl C, Wang X, Calvin Alexander E. 2013.

Improvements in ${ }^{230}$ Th dating, ${ }^{230}$ Th and ${ }^{234} U$ half-life values, and U-Th isotopic ma

Earthand Planetary Science Letters, 371-372: 82-91.

Chiarin V, Evllio R, De Waele J. 2015. Note di speleogenesi nei gessi di Brisighella e Rqutana. Memorie dell'Istituto Italiano di Speleologia, II(28): 113-118.

Columbu A, Be Waele J, Forti P, Montagna P, Picotti V, Pons-Branchu E, Hellstrom J, BaindDrysdale RN. 2015. Gypsum caves as indicators of climate-driven river inçision and aggradation in a rapidly uplifting region. Geology, 43(6): 539-542.

Cyr AJ, Granger DE. 2008. Dynamic equilibrium among erosion, river incision, and coastal uplift inthe northern and central Apennines, Italy. Geology, 36(2): 103-106. 
Dansgaard W, Johnsen SJ, Clausen HB, Dahl-Jensen D, Gundestrup NS, Hammer CU, Hvldberg CS, Steffensen JP, Sveinbjornsdottir AE, Jouzel J, Bond G. 1993. Evidence for general instability of past climate from a 250-kyr ice-core record. Nature, 364: 218-220.

De Waete J. 2010. Speleogenesi del complesso carsico di Rio Stella-Rio Basino. In II progentella-Basino. Lucci P., Forti P. (eds), Memorie dell'Istituto Italiano di Speleologia, II(23): 95-108.

De Wael J. 8 Pasini G. 2013. Intra-messinian gypsum palaeokarst in the Northern Apermpes and its palaeogeographic implications. Terra Nova, 25(3): 199-205. De Waelericcini L. 2008. Speleogenesi e morfologia dei sistemi carsici in rocce carbonatiche: In Atti del 45 Corso CNSS-SSI di III livello di geomorfologia carsica, PairsetM, Inguscio S, Marangella A. (eds.), Grottaglie, 23-74.

De Wael Borti P, Rossi A. 2011. II carsismo nelle evaporiti dell'Emilia Romagna. In Speteologia e geositi carsici in Emilia Romagna, Lucci P, Rossi A. (eds.), Pitagora, Botogna, 25-59.

De Wael J, Ferrarese F, Granger D, Sauro F. 2012a. Landscape evolution in the Tacchi ar a (G) cayenediments. Geografia Fisica e Dinamica Quaternaria, 35: 119-127.

De Waele J, Anfossi G, Campo B, Cavalieri F, Chiarini V, Emanuelli V, Grechi U, Nanni P, Savoryli F. 2012b. Geomorphology of the Castel de'Britti area (Northern Apenpines, Italy): an example of teaching geomorphological mapping in a traansal and practical way. Journal of Maps, 8(3): 231-235. 
De Waele J, Fabbri F, Forti P, Lucci P, Marabini S. 2013. Evoluzione speleogenetica del sistema carsico del re Tiberio (Vena del gesso Romagnola). Memorie dell'Istituto Italiano di Speleologia, II(26): 81-101.

Demaria D. 2002. Emilia Romagna. In Le aree carsiche gessose d'Italia. Madonia G., Forti P.'(eds). Memorie dell'Istituto Italiano di Speleologia, II(14): 159-184.

Emiliani Cons. Pleistocene temperatures. Journal of Geology, 63: 538-578.

Drysdale RN, Bence TB, Hellstrom JC, Couchoud I, Greig A, Bajo P, Zanchetta G, Isola I, Spotl g Baneschi I, Regattieri E, Woodhead JD. 2012. Precise microsampling of

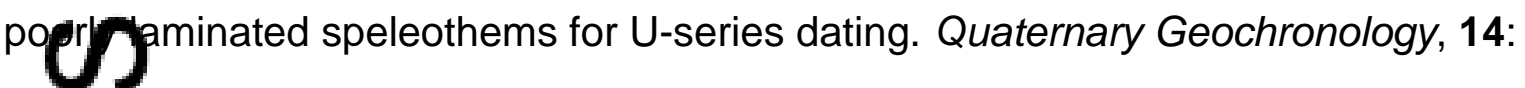

38

Fairchild IJ, Baker A. 2012. Appendix 1: Archiving Speleothems and Speleothem Data. In Spcrovihem Science: From Process to Past Environments, Fairchild IJ, Baker A. (eds. Wiley-Blackwell, 368-370.

Falgueres 2003. ESR dating and the human evolution: Contribution to the chronology of me eartiest humans in Europe. Quaternary Science Reviews, 22: 1345-1351.

Farrant AR, Smart PL, Whitaker FF, Tarling DH. 1995. Long-term Quaternary uplift rates inferrey from limestone caves in Sarawak, Malaysia. Geology, 23(4): 357-360.

Ford D, Wulliams P. 2007. Karst geomorphology and hydrology. (Ed.) John Wiley \& Sons, Chichester, pp. 562.

Forti P. 2000y sistemi carsici. In Risposta dei processi geomorfologici alle variazioni ambientali. Biancotti A., Motta M. (eds). Briganti, Genova, 246-251. 
Forti P, Chiesi M. 2001. Idrogeologia, idrodinamica e meteorologia ipogea dei Gessi di Albinea, con particolare riguardo al Sistema carsico afferente alla Tana della Mussina di Borzano (ER-RE 2) (Albinea-Reggio Emilia). Memorie dell'Istituto Italiano di Speleologia, II(11): 115-139.

Forti P, Sauro U. 1996. The gypsum karst of Italy. International Journal of Speleology, 25:-250.

Gunders@n, K. L., Pazzaglia, F. J., Picotti, V., Anastasio, D. A., Kodama, K. P., Rittenour, T. (Fra)kel, K. F., Ponza, A., Berti, C., and Negri, A. 2014. Unraveling tectonic and clipacy controls on synorogenic growth strata (Northern Apennines, Italy). Gedonical Society of America Bulletin, 126(3-4): 532-552.

Häuselmann P, Mihevc A, Pruner P, Horáček I, Čermák S, Hercman H, Sahy D, Fiebig M, Zupramtiajna N, Bosák P. 2015. Snežna jama (Slovenia): Interdisciplinary dating of casdiments and implication for landscape evolution. Geomorphology, 247: 10-

Hellstrom J. Z003. Rapid and accurate U/Th dating using parallel ion-counting multicollector ICP-MS. Journal of Analytical Atomic Spectrometry, 18: 1346-1351. Hellstrom J.2p06. U-Th dating of speleothems with high initial ${ }^{230}$ Th using stratigraphical copatraint. Quaternary Geochronology, 1(4): 289-295.

Klimchouk AB, 2000. Speleogenesis in noncarbonate lithologies. In Speleogenesis, everuty of karst aquifers, Klimchouk AB, Ford DC, Palmer AN, Dreybrodt W. (eds.) National Speleological Society, Huntsville, 430-442. 
Klimchouk AB. 2007. Hypogene speleogenesis: hydrogeological and morphogenetic perspective. National Cave and Karst Research Institute, Carlsbad. Special Paper № 1, Carlsbad.

Klimchouk AB. 2012. Ukraine Giant Gypsum Caves. In Encyclopedia of caves, Gunn J. (ed.), Fitzroy Dearborn, New York, 827-833.

Krijgsmangen F, Raffi I, Sierro F, Wilson D. 1999. Chronology, causes and pression of the Messinian salinity crisis. Nature, 400(6745): 652-655.

Lisiecki L, Rymo ME. 2005. A Pliocene-Pleistocene stack of 57 globally distributed beytlo ${ }^{18} \mathrm{O}$ records. Paleoceanography, 20(1): 1-17.

Lugli S, inary V, Roveri M, Scheiber BC. 2010. The Primary Lower Gypsum in the Mediterranean: a new facies interpretation for the first stage of the Messinian salminycrisis. Palaeogeography, Palaeoclimatology, Palaeoecology, 297(1): 83-99. Marabini O. Oviani M, Vai GB, Vigliotti L. 1995. Yellow sand facies with Arctica Islandica: lowstand signature in an early Pleistocene Front-Apennine Basin. Giornale di Georogia, 57(1-2): 259-275.

Maslin MA, Ridgwell AJ. 2005. Mid-Pleistocene revolution and the 'eccentricity myth'. Gfogical Society, London, Special Publications, 247(1): 19-34.

Miari M. Lمص2 L'eneolitico: In Archeologia dell'Apennino romagnolo: il territorio di Riolo Terme, Guarnieri C. (ed.), Imola, 30-33.

Muttoni G, ogcano C, Garzanti E, Ghielmi M, Piccin A, Pini R, Rogledi S, Sciunnach D. 2003. Dnset of major Pleistocene glaciations in the Alps. Geology, 31(11): 989-992. 
Muttoni, G., Scardia, G., Kent, D. V., Morsiani, E., Tremolada, F., Cremaschi, M., Peretto, C. 2011. First dated human occupation of Italy at $\sim 0.85 \mathrm{Ma}$ during the late Early Pleistocene climate transition. Earth and Planetary Science Letters, 307(3-4): 241252.

Negrini C.2007. Re Tiberio: In Archeologia dell'Apennino romagnolo: il territorio di Riolo Tementernieri C. (ed.), Imola, 51-52.

N.G.I.C.P members. 2004. High-resolution record of Northern Hemisphere climate ex ending into the last interglacial period. Nature, 431(7005): 147-151.

Pain C., Giliz) C. 1995. Inversion of relief - a component of landscape evolution. Genmerphology, 12(2): 151-165.

Pasini G. 1966. I canali di volta nelle grotte carsiche del Bolognese. Nuove ipotesi sulla Iorormazione: Unpublished Graduation Short Experimental Thesis. Library Dept. Easthand Geoenvironmental Sciences of the Bologna University, no. 280, p. 83.

Pasini G. 1967 . Osservazioni sui canali di volta delle grotte bolognesi. Le Grotte d'Italia, v(I).17-74.

Pasini G.1969. Fauna a mìammiferi del Pleistocene superiore in un paleoinghiottitoio ca sICgpresso Monte Croara (Bologna). Le Grotte d'Italia, IV(4): 1-46.

Pasini G. 1073. Sull'importanza speleogenetica dell'«Erosione antigravitativa. Le Grotte d'Italia,IV(4): 297-308.

Pasini G. ₹ov9. A terminological matter: paragenesis, antigravitative erosion or antigrawitational erosion? International Journal of Speleology, 38(2): 129-128. 
Pasini G. 2012. Speleogenesis of the "Buco dei Vichi" inactive swallow hole (Monte Croara karst sub-area, Bologna, Italy), an outstanding example of antigravitative erosio (or "paragenesis" in selenitic gypsum. An outline of the "post-antigravitative erosion". Acta Carsologica, 41(1): 15-34.

Piccini L.2011. Speleogenesis in highly geodynamic contexts: the quaternary evolution of Morchia multi-level karst system (Alpi Apuane, Italy). Geomorphology, 134(12) $49-61$.

Piccini L, De YVaele J, Galli E, Polyak VJ, Bernasconi SM, Asmerom Y. 2015. Sulphuric acjel ppeleogenesis and landscape evolution: Montecchio cave, Albegna river valley (Seuthern Tuscany, Italy). Geomorphology, 229: 134-143.

Picotti V, Pazzaglia FJ. 2008. A new active tectonic model for the construction of the NGtirern Apennines mountain front near Bologna (Italy). Journal of Geophysical Restarch, 113, B08412.

Pisias NG,More T. 1981. The evolution of Pleistocene climate: a time series approach. Eartr and Planetary Science Letters, 52(2): 450-458.

Plan L, Ţchegg C, De Waele J, Spötl C. 2012. Corrosion morphology and cave wall alteratipn in an Alpine sulfuric acid cave (Kraushohle, Austria). Geomorphology, 160:-15-54.

Polyak VJ, MçIntosh WC, Güven N, Provencio P. 1998. Age and Origin of Carlsbad Cavery and Related Caves from ${ }^{40} \mathrm{Ar} /{ }^{39} \mathrm{Ar}$ of Alunite. Science, 279(5358): 1919- 
Polyak, VJ., Provencio, P., Asmerom, Y., 2016. U-Pb dating of speleogenetic dolomite: A new sulfuric acid speleogenesis chronometer. International Journal of Speleology, 45(2): 103-109.

Pons-Branchu E, Douville E, Roy-Barman M, Dumont E, Branchu P, Thil F, Frank N, Bơrdier L, Borst W. 2014, A geochemical perspective on Parisian urban history bath dating, laminae counting and yttrium and REE concentrations of regent carbonates in underground aqueducts. Quaternary Geochronology, 24: 4453

Roveri MFjer R, Krijgsman W, Lofi J, Lugli S, Manzi V, Sierro FJ, Bertini A, Camadenghi A, De Lange G, Govers R, Hilgen FJ, Hübscher C, Meijer PT, Stoica M. 2014. The Messinian Salinity Crisis: past and future of a great challenge for marmesciences. Marine Geology, 352: 25-58.

Sasowsk(1998. Determining the age of what is not there. Science, 279(5358): 1874.

Scroxton Gagan MK, Dunbar GB, Ayliffe LK, Hantoro WS, Shen C-C, Hellstrom JC, zmau J-X, Cheng H, Edwards RL, Sun H, Rifai H. 2016. Natural attrition and growth frequency variations of stalagmites in southwest Sulawesi over the past 530,000 years. Palaeogeography, Palaeoclimatology, Palaeoecology, 441: 823-833.

Simoni A Danza A, Picotti V, Berti M, Dinelli E. 2013. Earthflow sediment production and Hglocene sediment record in a large Apennine catchment. Geomorphology, 188:

42-00

Sirocko F, Claussen M, Sánchez Goñi MF, Litt T. (eds) 2006. The climate of past interglacials. Developments in Quaternary Science, 7: 622 p. 
Spötl C, Mattey D. 2012. Scientific drilling of speleothems-a technical note. International Journal of Speleology, 41(1): 29-34.

Tassy A, Mocochain L, Bellier O, Braucher R, Gattacceca J, Bourlès D. 2013. Coupling cosmogenic dating and magnetostratigraphy to constrain the chronological evolution of peri-Mediterranean karsts during the Messinian and the Pliocene: Exurdène Valley, Southern France. Geomorphology, 189: 81-92.

Tzedakis PC, Raynaud D, McManus JF, Berger A, Brovkin V, Kiefer T. 2009. Interglacial di ersity. Nature Geoscience, 2(11): 751-755.

Vai GB, Maymi IP. 2001. Anatomy of an orogen: the Apennines and adjacent Meditorranean. Kluwer Academic Publishers, Dordrecht, Netherlands, pp. 631. Wegmann KW, Pazzaglia FJ. 2009. Late Quaternary fluvial terraces of the Romagna and Martre Apennines, Italy: climatic, lithologic, and tectonic controls on terrace getsis in an active orogen. Quaternary Science Reviews, 28(1): 137-165.

White, W. 1988. Geomorphology and Hydrology of Karst Terrains. Oxford University Fress, New York, pp. 464.

Williams, P. W., 1982. Speleothem dates, Quaternary terraces and uplift rates in New Zearany. Nature, 298 (5871): 257-260.

Woodhe_Hellstrom J, Maas R, Drysdale R, Zanchetta G, Devine P, Taylor E. 2006. U-Pb geochronology of speleothems by MC-ICPMS. Quaternary Geochronology, 1 

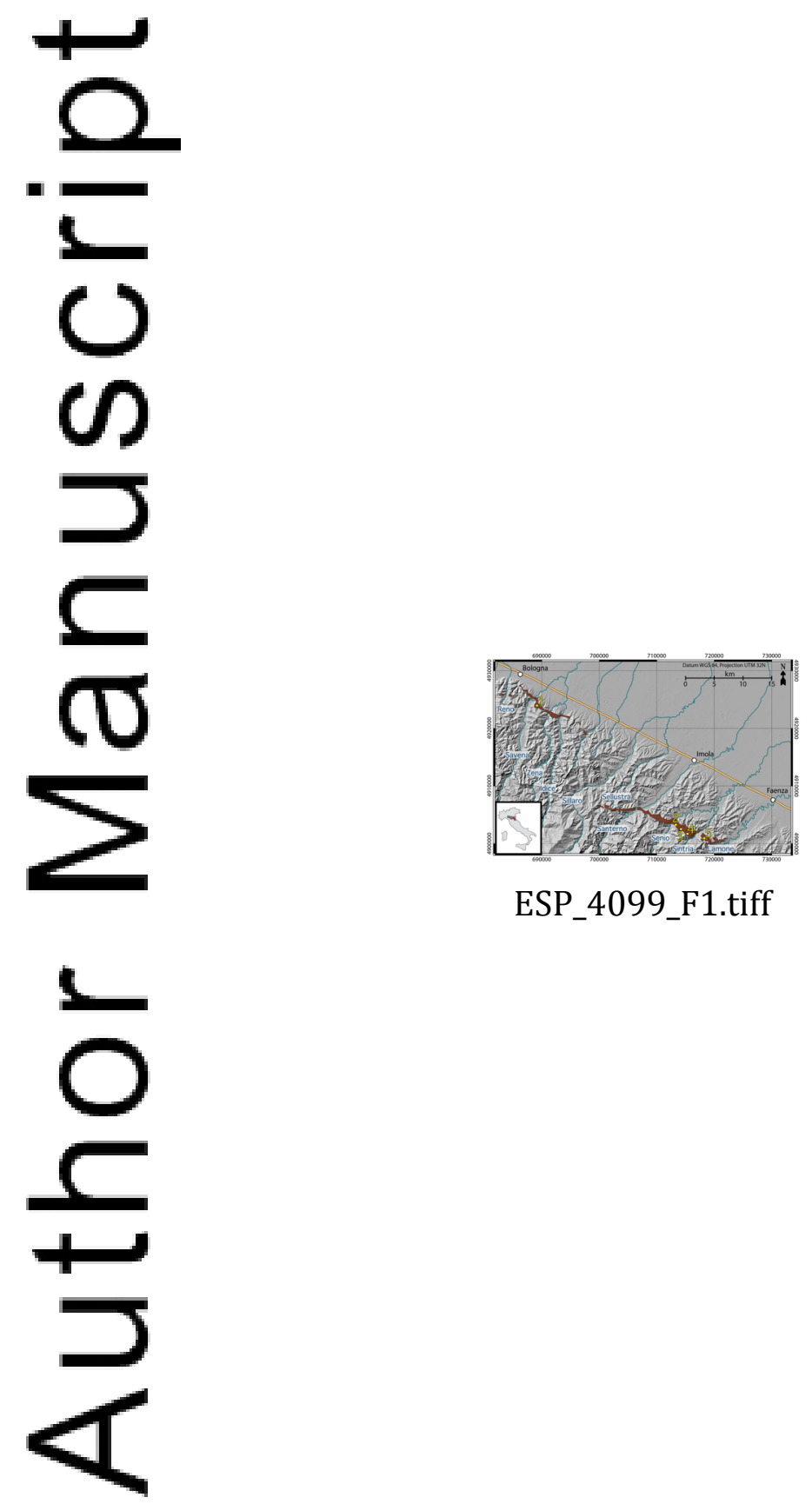

This article is protected by copyright. All rights reserved. 


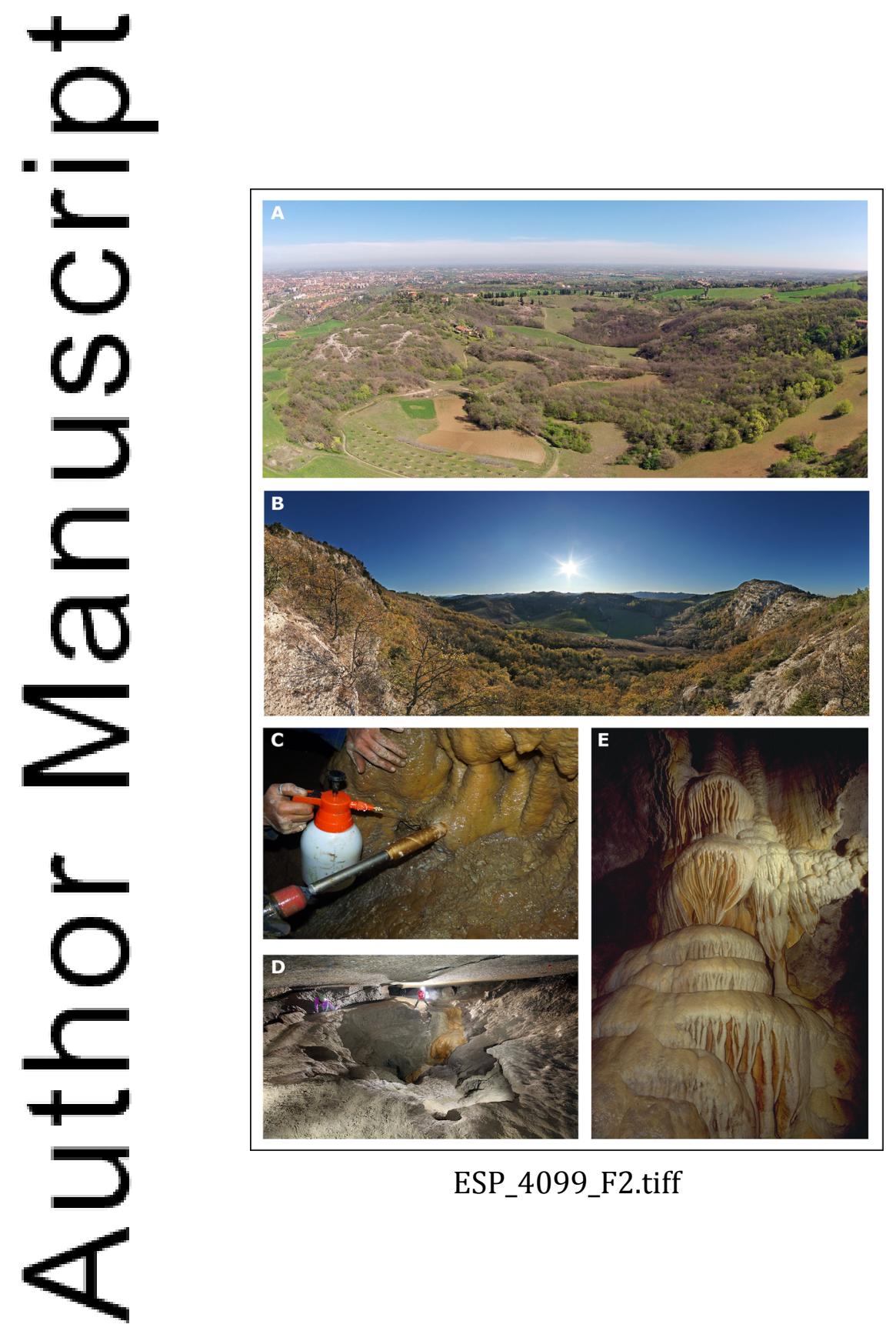

This article is protected by copyright. All rights reserved. 

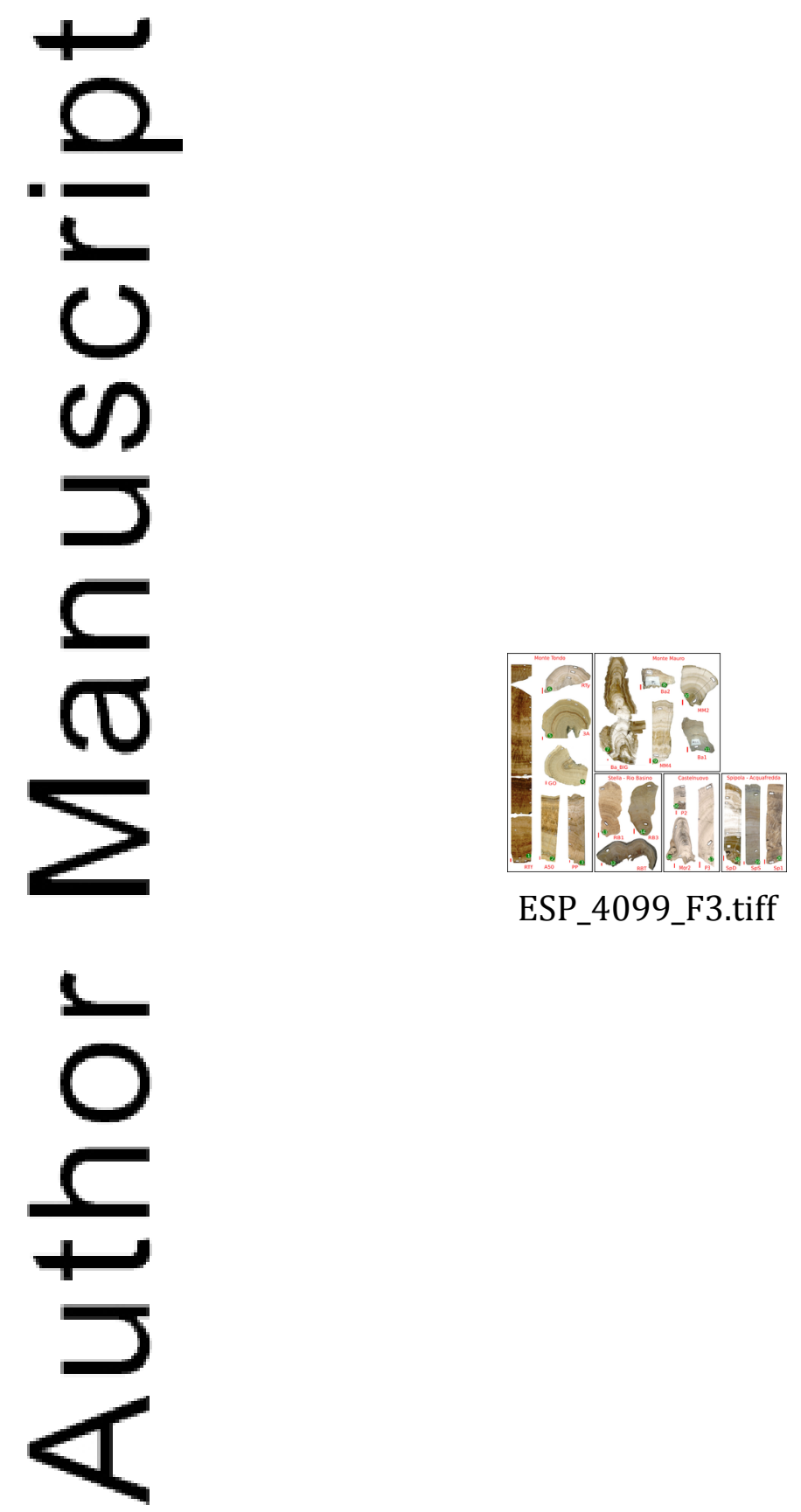

This article is protected by copyright. All rights reserved. 

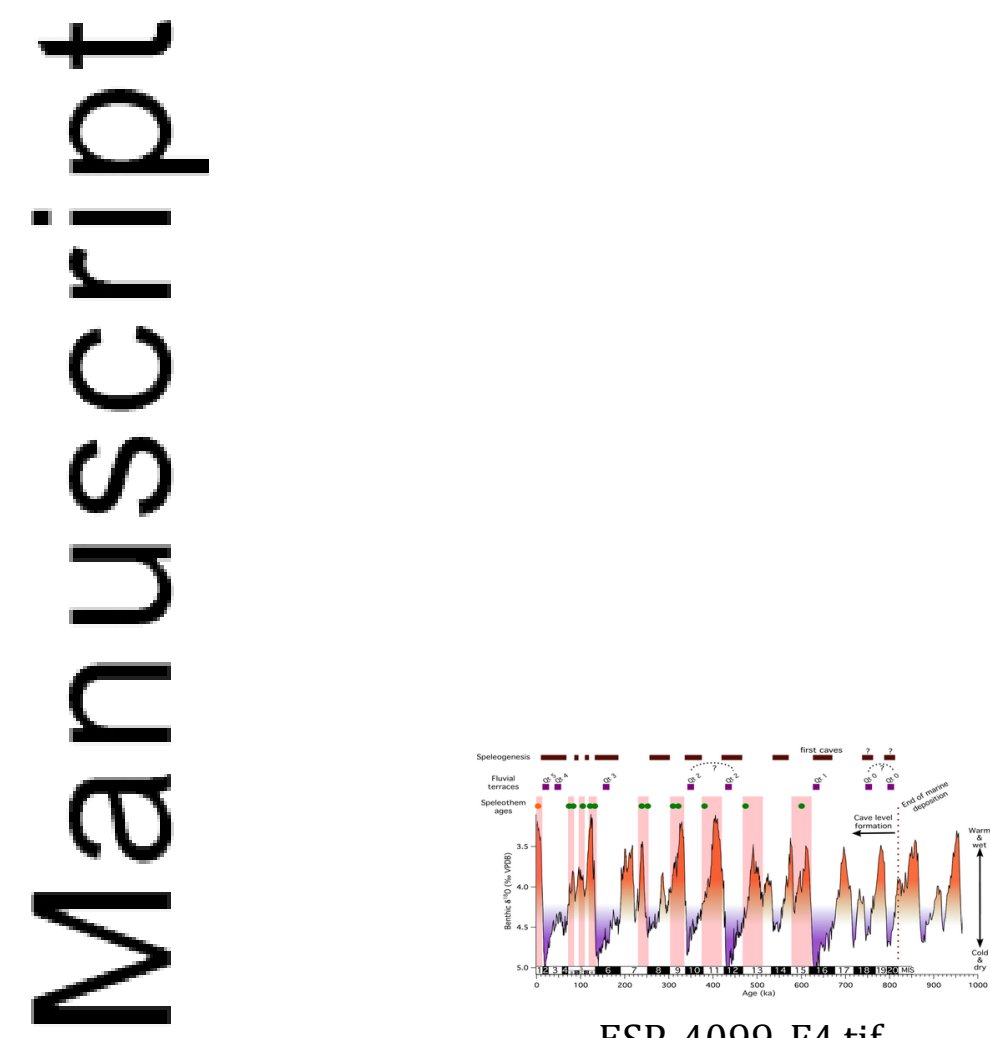

ESP_4099_F4.tif

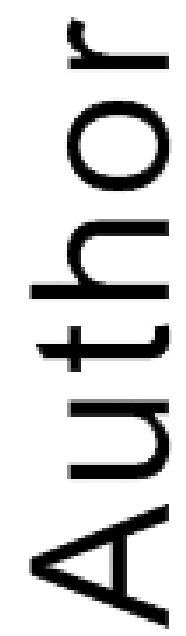

This article is protected by copyright. All rights reserved. 

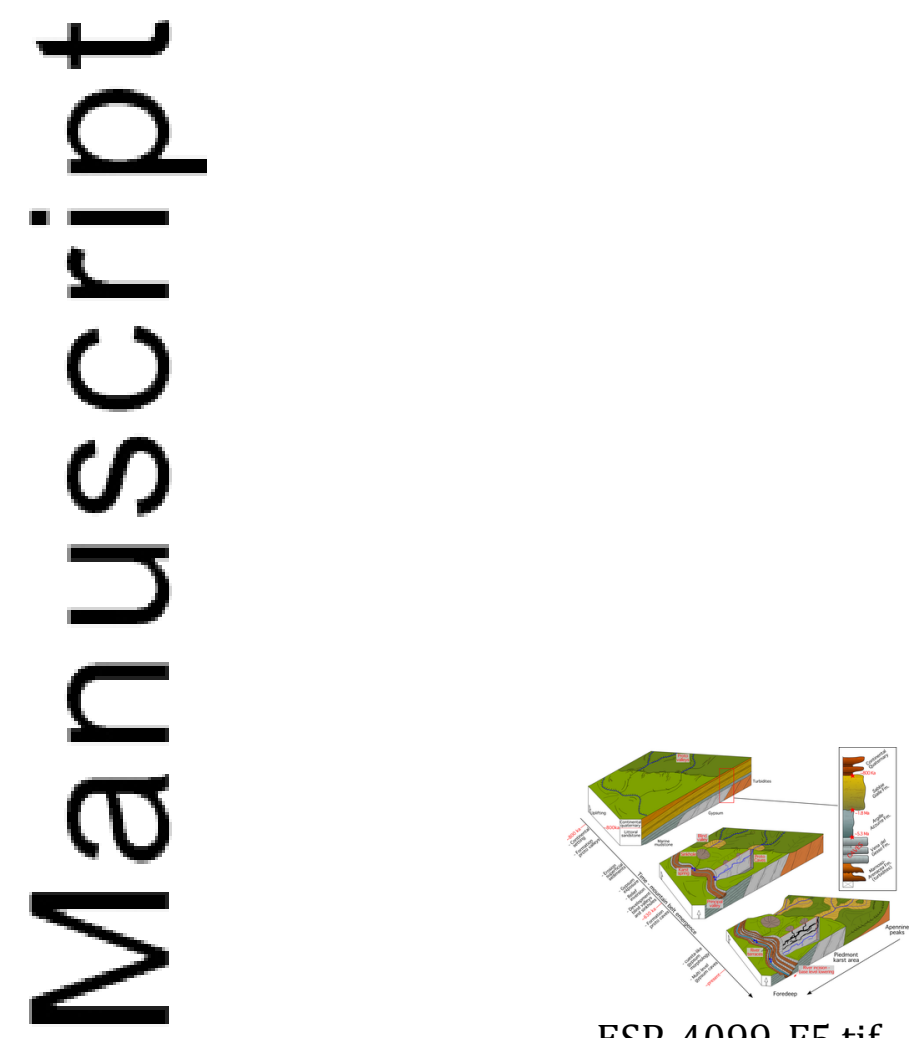

ESP_4099_F5.tif

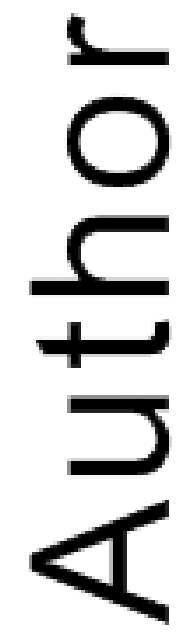

This article is protected by copyright. All rights reserved. 

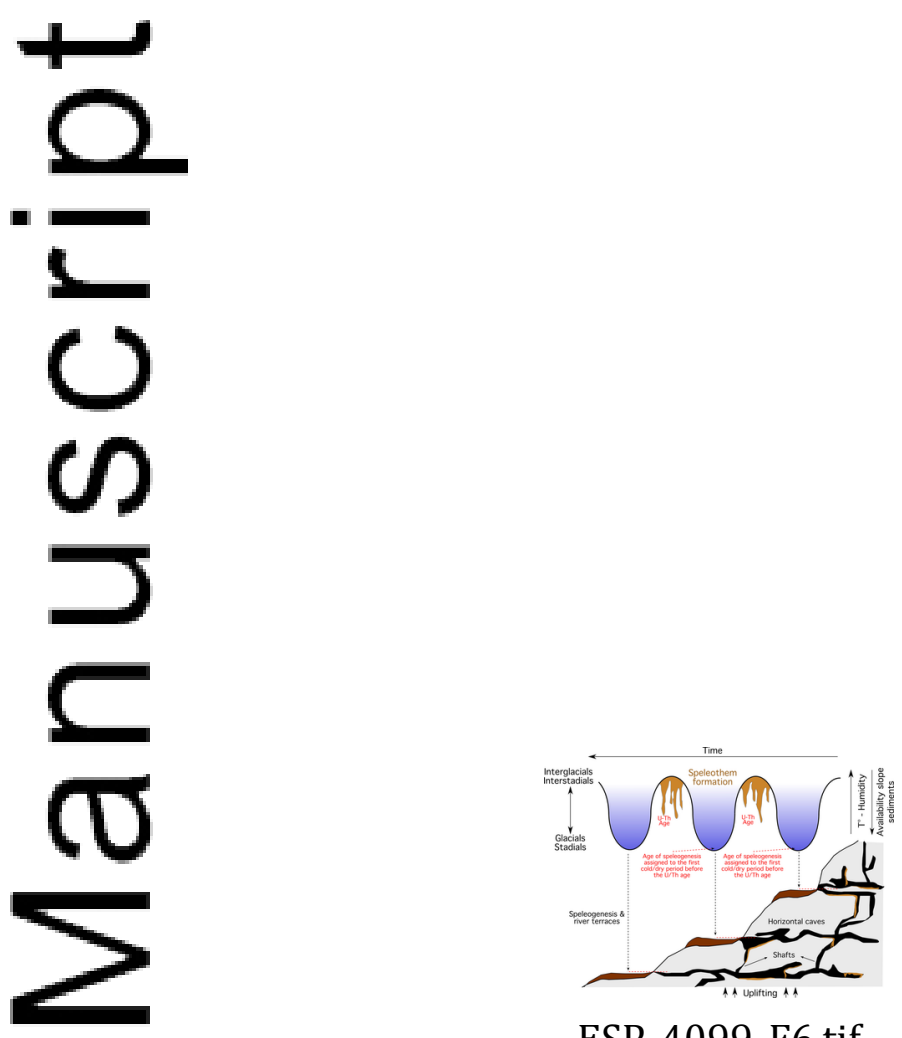

ESP_4099_F6.tif

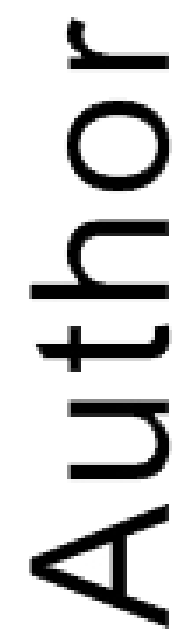

This article is protected by copyright. All rights reserved. 

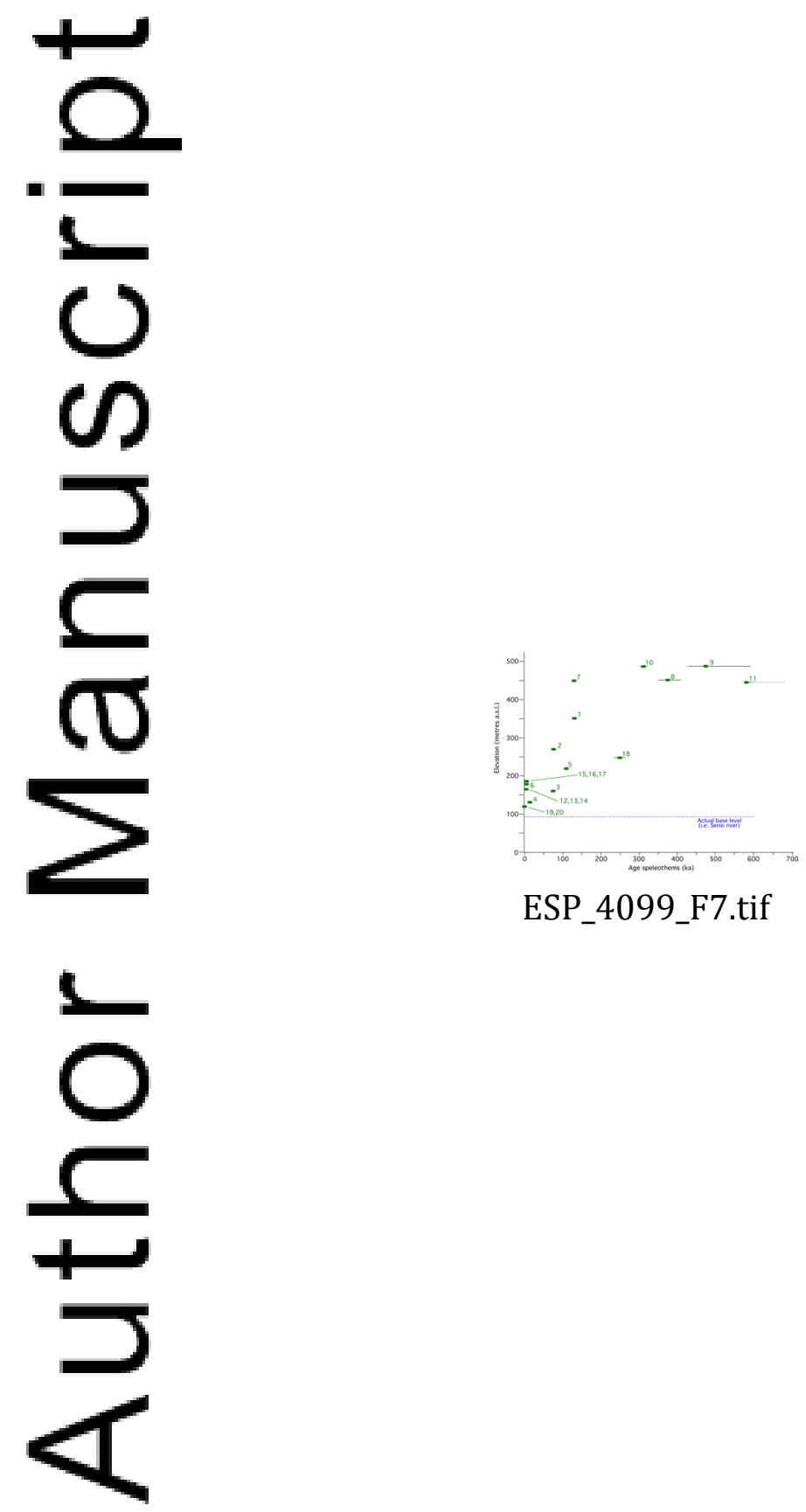

This article is protected by copyright. All rights reserved. 


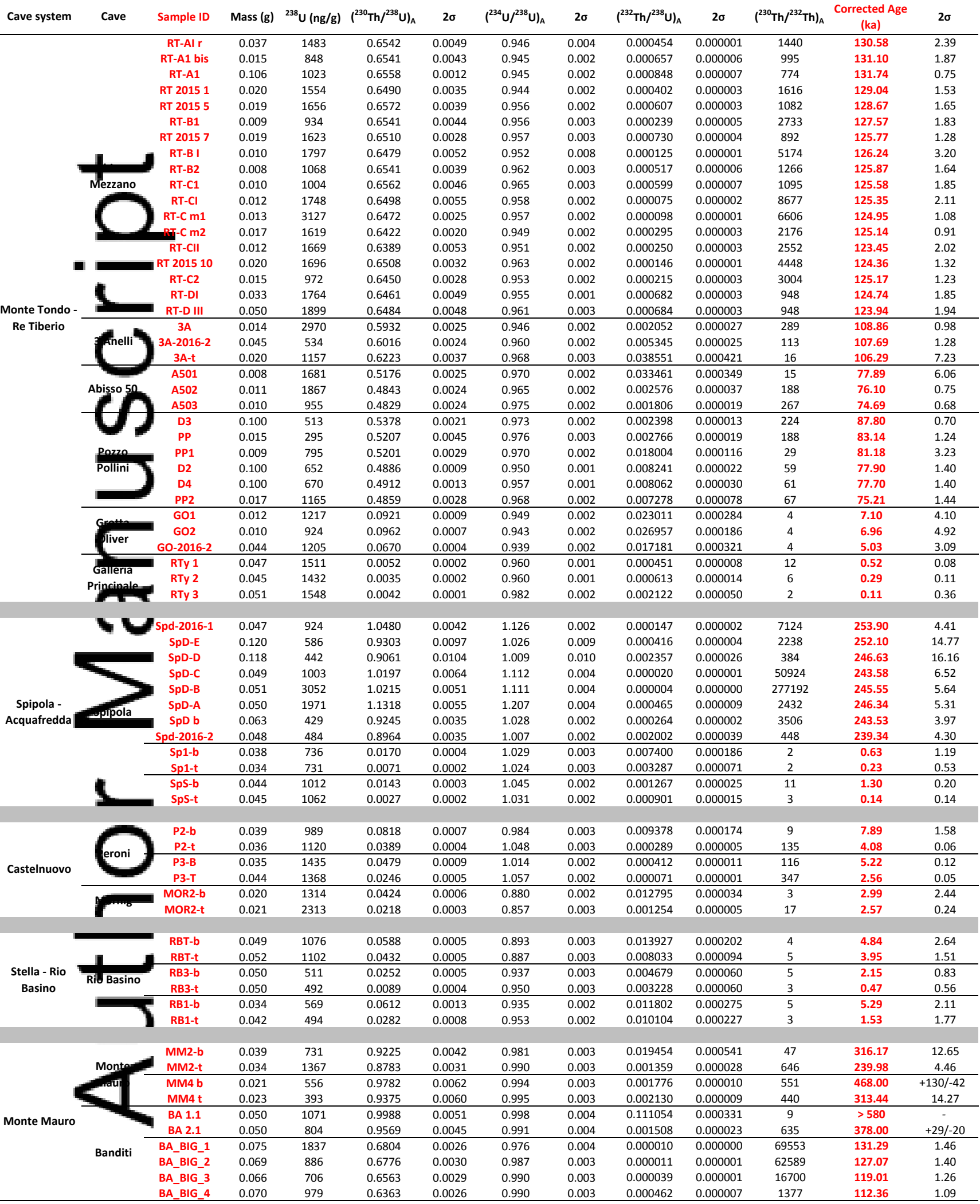




\section{University Library}

\section{- M M N E R VA A gateway to Melbourne's research publications}

Minerva Access is the Institutional Repository of The University of Melbourne

Author/s:

Columbu, A;Chiarini, V;De Waele, J;Drysdale, R;Woodhead, J;Hellstrom, J;Forti, P

Title:

Late quaternary speleogenesis and landscape evolution in the northern Apennine evaporite areas

Date:

2017-08-01

\section{Citation:}

Columbu, A., Chiarini, V., De Waele, J., Drysdale, R., Woodhead, J., Hellstrom, J. \& Forti, P. (2017). Late quaternary speleogenesis and landscape evolution in the northern Apennine evaporite areas. EARTH SURFACE PROCESSES AND LANDFORMS, 42 (10), pp.1447-1459. https://doi.org/10.1002/esp.4099.

Persistent Link:

http://hdl.handle.net/11343/292371 